\title{
Growth Behaviors of ZnO Nanorods Grown with the Sn-Based Bilayer Catalyst-Covered Substrates
}

\author{
Dong-Hau Kuo and Bo-Jie Chang \\ Department of Materials Science and Engineering, National Taiwan University of Science and Technology, Taipei 10607, Taiwan \\ Correspondence should be addressed to Dong-Hau Kuo, dhkuo@mail.ntust.edu.tw
}

Received 12 May 2011; Accepted 8 July 2011

Academic Editor: Renzhi Ma

Copyright ( 2011 D.-H. Kuo and B.-J. Chang. This is an open access article distributed under the Creative Commons Attribution License, which permits unrestricted use, distribution, and reproduction in any medium, provided the original work is properly cited.

The growth of $\mathrm{ZnO}$ nanorods performed at $700^{\circ} \mathrm{C}$ with the mixture of $\mathrm{Zn}$ and $\mathrm{ZnO}$ as the $\mathrm{Zn}$ source was investigated by having the catalysts in bilayer configurations of $\mathrm{Sn}$ (top)/Au (bottom), Sn/Al, Sn/Ni, and $\mathrm{Sn} / \mathrm{In}$. These catalyst layers were preannealed at $700^{\circ} \mathrm{C}$ or $850^{\circ} \mathrm{C}$ in a gas mixture of argon and hydrogen. The variations in the process parameters are to give the modulations in growing $\mathrm{ZnO}$ rods for the purpose of investigating the growth behaviors. The results show that the different compositions and configurations of bilayer catalysts can lead to different reactions and interdiffusions or in different kinetic performance, which will produce different sizes and states of catalyst templates for growing different sizes of the $\mathrm{ZnO}$ rods. The small-diameter $\mathrm{ZnO}$ nanorods with a hexagonal cross-section at the size of 70-150 nm were obtained from the Sn/Ni catalyst systems preannealed at $850^{\circ} \mathrm{C}$.

\section{Introduction}

Zinc oxide $(\mathrm{ZnO})$ with a wide band gap of $3.37 \mathrm{eV}$ and large exciton-binding energy $(60 \mathrm{meV})$ has been an attractive semiconductor for optoelectronic applications in light emitting diodes and laser diodes at room temperature. Nanometer scale, one-dimensional (1D) materials, such as nanowires (NWs), nanorods, nanobelts, and nanotubes, have become of great interest due to their importance in basic scientific research, and potential technological applications in nanolaser, field emission devices, photovoltaic, piezoelectric transducer, photocatalysts, chemical and biosensors, and so forth $[1,2]$.

Vapor phase-grown one-dimensional (1D) $\mathrm{ZnO}$ nanomaterials were mainly obtained by using the $\mathrm{Zn}$ and $\mathrm{Zn}+\mathrm{ZnO}$ sources with the growth temperatures at $650^{\circ} \mathrm{C} \sim 900^{\circ} \mathrm{C}[3-$ $6]$, the $\mathrm{ZnO}+\mathrm{C}$ source at $850^{\circ} \mathrm{C}-1100^{\circ} \mathrm{C}[7,8]$, and the diethyl zinc source at $350-500^{\circ} \mathrm{C}[9,10] .1 \mathrm{D} \mathrm{ZnO}$ can grow at the uncoated substrates with the self-catalytic vapor-liquidsolid (VLS) growth mechanism. The major catalysts used on the coated substrates to grow $1 \mathrm{D} \mathrm{ZnO}$ are gold, nickel, and tin. VLS mechanism has been related to the growth of $1 \mathrm{D} \mathrm{ZnO}$ with catalysts on its tips, and it is the vapor-solid
(VS) growth mechanism for those without catalysts on tips. Although Au catalysts played an important role in forming the $1 \mathrm{D} \mathrm{ZnO}$, some grown $1 \mathrm{D} \mathrm{ZnO}$ had the Au droplets $[5,7]$, and some had no catalysts on the tips $[11,12]$. Ni was also used as a catalyst on the coated substrates. Umar et al. grew hexagonal-shaped $\mathrm{ZnO}$ nanorods at $500^{\circ} \mathrm{C}-550^{\circ} \mathrm{C}$ in an oxygen atmosphere on preannealed $\mathrm{Ni}$-coated substrates with the Zn powder as a source material [3]. The Sn-based catalysts are the focus of this study for growing $\mathrm{ZnO}$ rods. $1 \mathrm{D} \mathrm{ZnO}$ grown above $1000^{\circ} \mathrm{C}$ on the uncoated substrates with the mixture of $\mathrm{ZnO}$ and $\mathrm{SnO}_{2}$ or $\mathrm{Sn}$ as source materials has pure Sn droplets observed on tips of nanowires [13-15]. These Sn droplets on the tips of ZnO NWs had the sizes 2fold larger than those of $\mathrm{ZnO}$ rods. If $1 \mathrm{D}$ nanomaterials were grown on the $\mathrm{Au}$-coated substrates with the mixture of $\mathrm{ZnO}$ and $\mathrm{SnO}$ powders as a source material at $1000^{\circ} \mathrm{C}, \mathrm{Zn}_{2} \mathrm{SnO}_{4}$ nanowires with an inverse spinel structure were obtained $[16,17]$.

In the previous report, we had grown $1 \mathrm{D} \mathrm{ZnO}$ nanorods on the untreated or preannealed bilayer catalyst-covered substrates to explore their growth behaviors and micromechanisms [18]. Three kinds of the bilayer catalysts were $\mathrm{Au}$ (the top layer)/Al (the bottom layer), $\mathrm{Au} / \mathrm{Ni}$, and $\mathrm{Au} / \mathrm{In}$ or 


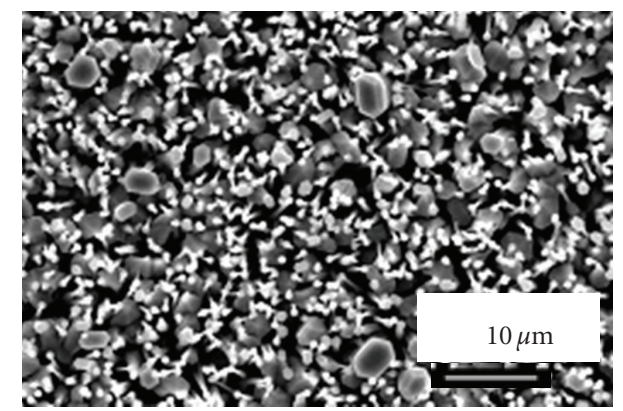

(a)

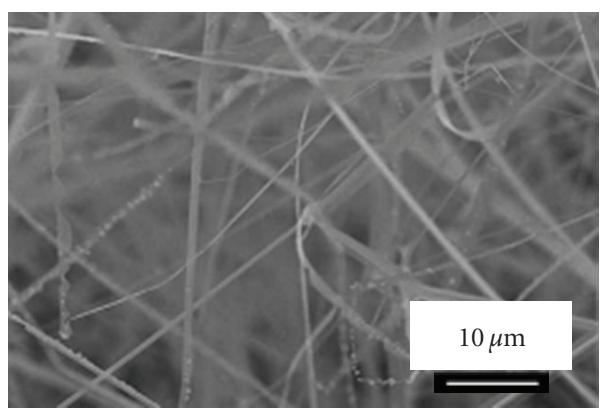

(c)

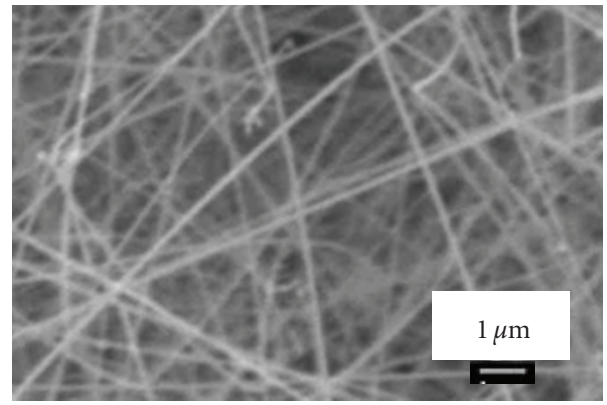

(b)

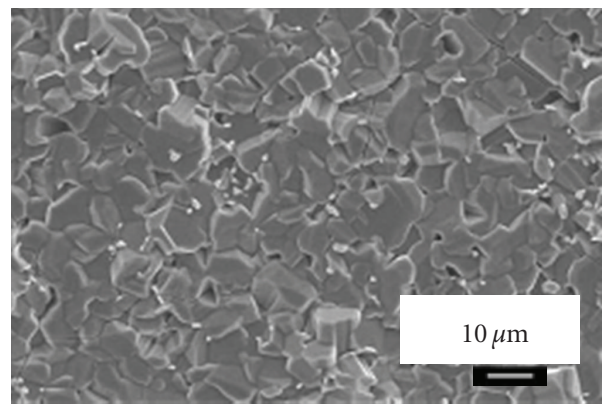

(d)

Figure 1: Surface morphologies of $\mathrm{ZnO}$ grown at (a) $600^{\circ} \mathrm{C}$, (b) $700^{\circ} \mathrm{C}$, (c) $800^{\circ} \mathrm{C}$, and (d) $900^{\circ} \mathrm{C}$ for $2 \mathrm{~h}$ on Au-coated substrates by thermal evaporation with a $\mathrm{Zn}$ mixture of $\mathrm{Zn}$ and $\mathrm{ZnO}$ in a weight ratio of $1: 1$.

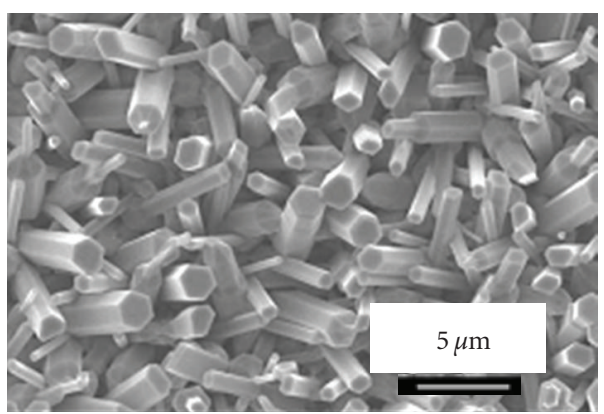

(a)

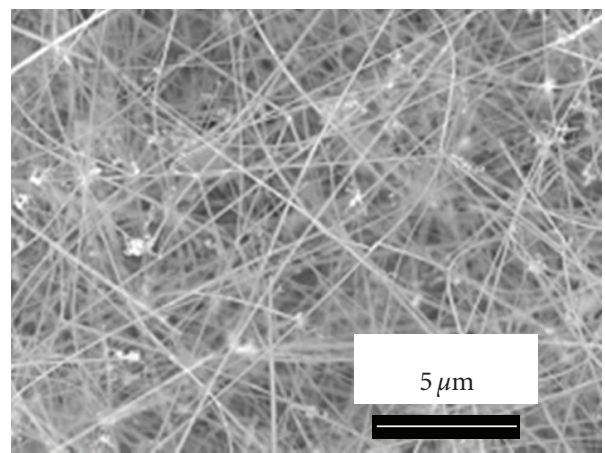

(b)

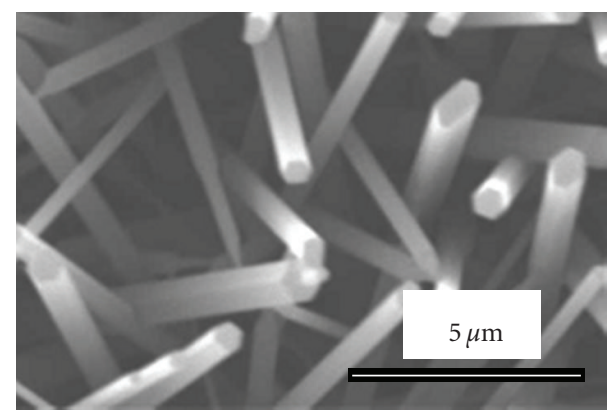

(c)

Figure 2: Surface morphologies of $\mathrm{ZnO}$ grown at $700^{\circ} \mathrm{C}$ for $2 \mathrm{~h}$ on Au-coated substrates by thermal evaporation with a $\mathrm{Zn}$ mixture of $\mathrm{Zn}$ and $\mathrm{ZnO}$ in weight ratios of (a) $2: 1$, (b) $1: 1$, and (c) $1: 2$. 


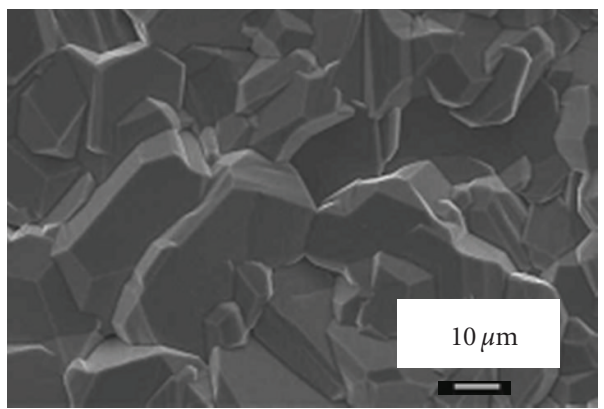

(a)

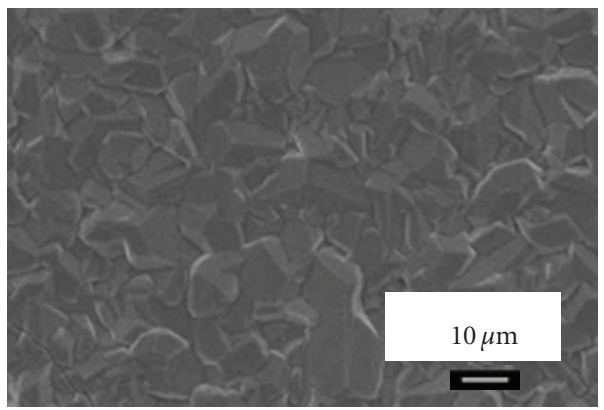

(c)

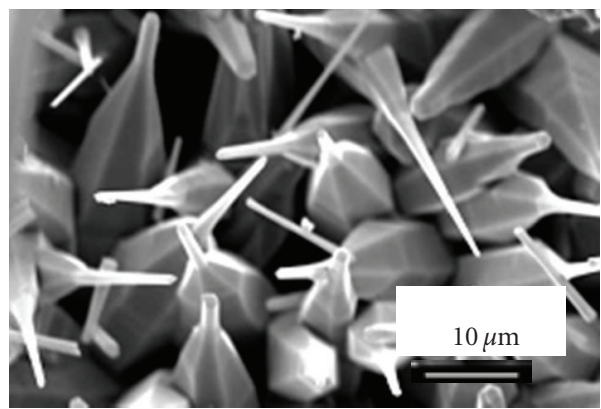

(b)

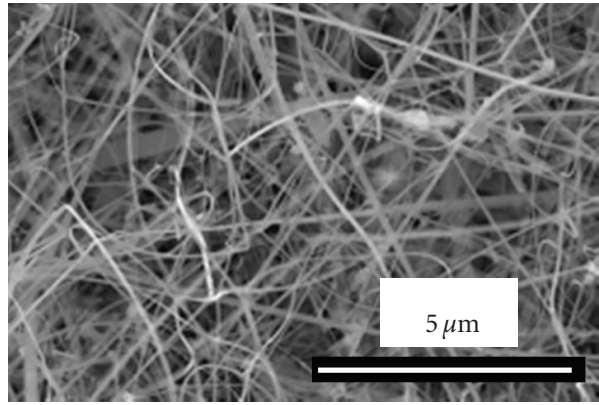

(d)

Figure 3: Surface morphologies of $\mathrm{ZnO}$ grown at $700^{\circ} \mathrm{C}$ for $2 \mathrm{~h}$ on (a) Al-, (b) Ni-, (c) In-, and (d) Sn-sputtering coated substrates by thermal evaporation with a $\mathrm{Zn}$ mixture of $\mathrm{Zn}$ and $\mathrm{ZnO}$ in a weight ratio of $1: 1$.

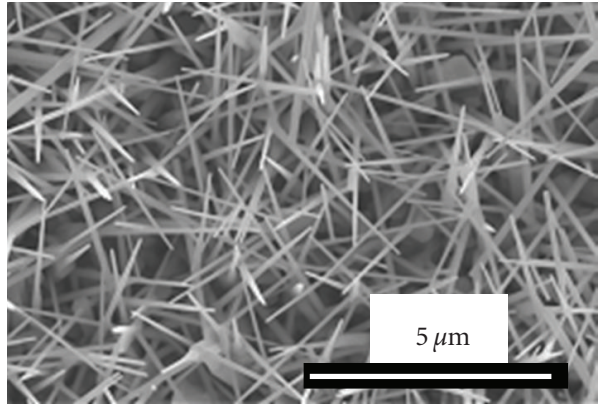

(a)

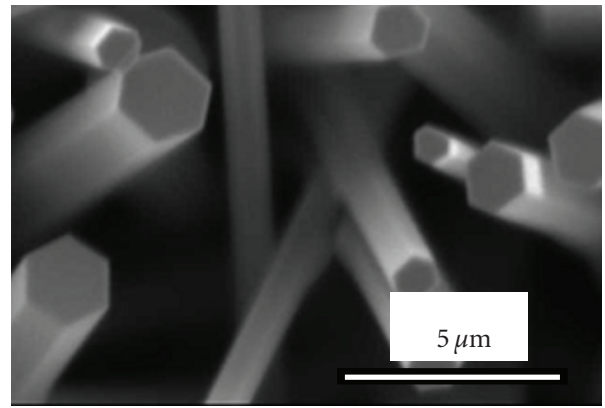

(b)

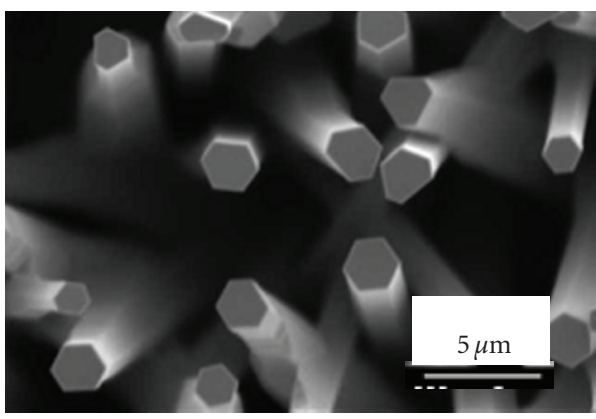

(c)

FIgURE 4: Surface morphologies of $\mathrm{ZnO}$ grown at $700^{\circ} \mathrm{C}$ for $2 \mathrm{~h}$ on (a) untreated, (b) $700^{\circ} \mathrm{C}$ preannealed, and (c) $850^{\circ} \mathrm{C}$ preannealed $\mathrm{Sn} / \mathrm{Au}$ substrates by thermal evaporation with a $\mathrm{Zn}$ mixture of $\mathrm{Zn}$ and $\mathrm{ZnO}$ in a weight ratio of $1: 1$. 


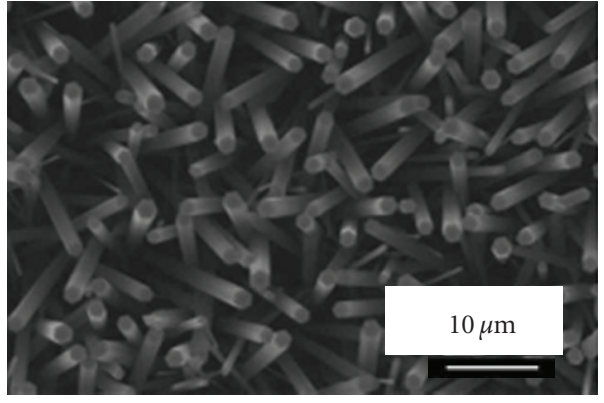

(a)

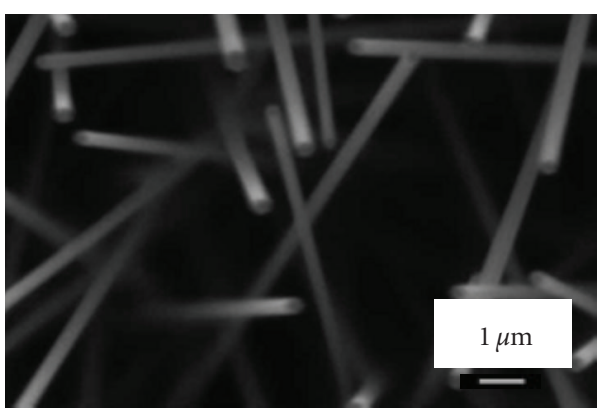

(c)

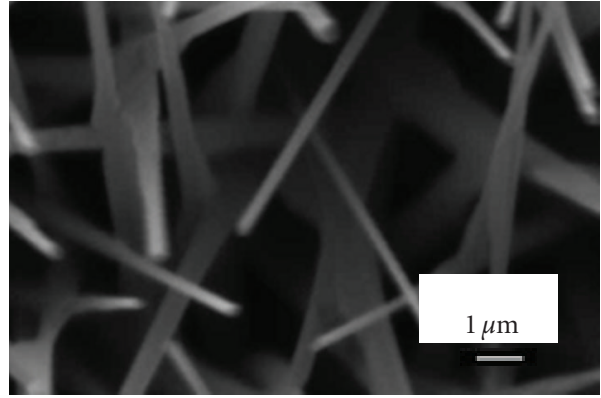

(b)

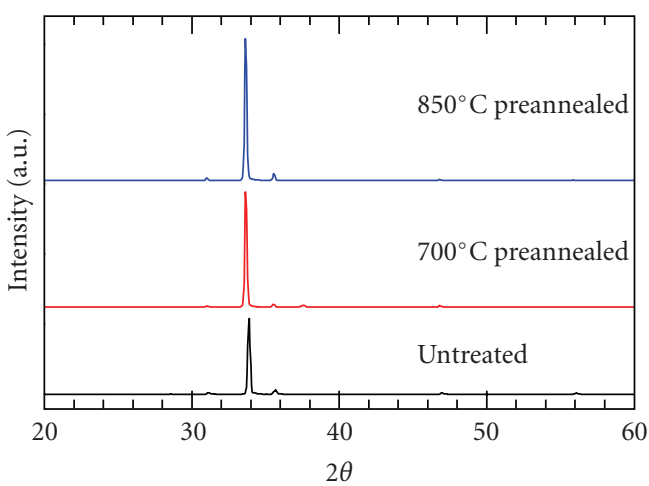

(d)

Figure 5: Surface morphologies of $\mathrm{ZnO}$ grown at $700^{\circ} \mathrm{C}$ for $2 \mathrm{~h}$ on (a) untreated, (b) $700^{\circ} \mathrm{C}$ preannealed, and (c) $850^{\circ} \mathrm{C}$ preannealed $\mathrm{Sn} / \mathrm{Al}$ substrates by thermal evaporation with a $\mathrm{Zn}$ mixture of $\mathrm{Zn}$ and $\mathrm{ZnO}$ in a weight ratio of $1: 1$. (d) X-ray diffraction patterns of $\mathrm{ZnO}$ nanorods grown on three types of $\mathrm{Sn} / \mathrm{Al}$ substrates.

the Au-based bilayer catalysts. The results indicated that the catalyst-confined nanowire growth via the VS growth mechanism was controlled by the size of catalysts, which was adjusted by alloying or catalyst reactions to change the surface tension and surface energy of the catalysts. There are few studies about the growth of hexagonal $1 \mathrm{D} \mathrm{ZnO}$ on the bilayer catalyst substrates with $\mathrm{Sn}$ as the top layer or on the $\mathrm{Sn}$-based substrates. Sn has a low melting temperature of $232^{\circ} \mathrm{C}$ and exists as a liquid at our growth condition of $700^{\circ} \mathrm{C}$. It has very different behaviors to those grown on the bilayer substrates with the Au catalyst on the top layer. After we have some knowledge about the growth on the Au-based systems, the investigations of the growth of hexagonal $\mathrm{ZnO}$ rods on the Sn-based substrates become interesting.

The purpose of this study is to study the states of bilayer catalysts on the growth micromechanism of $1 \mathrm{D} \mathrm{ZnO}$ by deliberately having different bilayer catalyst configurations with an Sn top layer and having different preannealing treatments. By differentiating and understanding the different $1 D$ $\mathrm{ZnO}$ growth behaviors, the growth of $1 \mathrm{D} \mathrm{ZnO}$ is expected to have a better control.

\section{Experimental}

$\mathrm{ZnO}$ nanowires were grown at $600-900^{\circ} \mathrm{C}$ for $2 \mathrm{~h}$ on the catalyst-coated $\mathrm{Si}$ wafer substrates under a mixture flow of 10-sccm (standard cubic centimeter per minute) $\mathrm{O}_{2}$ and 200 -sccm argon by thermal evaporation with a $\mathrm{Zn}$ mixture of $\mathrm{Zn}$ and $\mathrm{ZnO}$ at different weight ratios of $1.0 \mathrm{~g}: 0.5 \mathrm{~g}$ or $2: 1,1.0 \mathrm{~g}: 1.0 \mathrm{~g}$ or $1: 1$, and $0.5 \mathrm{~g}: 1.0 \mathrm{~g}$ or $1: 2$. Other $\mathrm{Zn}$ sources, for example, $\mathrm{Zn}, \mathrm{ZnO}, \mathrm{ZnCl}_{2}, \mathrm{Zn}+\mathrm{ZnCl}_{2}$, $\mathrm{ZnO}+\mathrm{ZnCl}_{2}$, and $\mathrm{Zn}+\mathrm{ZnCl}_{2}+\mathrm{ZnO}$, were also used. The $\mathrm{Zinc}$ source was put nearby the substrate. Single-layer catalysts of $\mathrm{Au}, \mathrm{Al}, \mathrm{Ni}, \mathrm{In}$, and $\mathrm{Sn}$ were deposited on $\mathrm{Si}$ wafer substrates by d.c. (direct current) magnetron sputtering. For the bilayer catalysts, there were one top layer $A$ and one bottom layer $B$, which was symbolized as $A / B$. In this study, the $A$ layer was fixed with $S n$ and the four constituted systems were $\mathrm{Sn} / \mathrm{Au}, \mathrm{Su} / \mathrm{Al}, \mathrm{Sn} / \mathrm{Ni}$, and $\mathrm{Sn} / \mathrm{In}$. These metallic catalyst layers had a thickness of $30-60 \mathrm{~nm}$ for each. The sputtered bilayer substrates were referred to as the untreated substrates. The effects of preannealing on the bilayer catalystcovered substrates before the growth of $1 \mathrm{D} \mathrm{ZnO}$ were studied by executing annealing at $700^{\circ} \mathrm{C}$ and $850^{\circ} \mathrm{C}$ for $30 \mathrm{~min}$ in a tube furnace under the atmosphere of argon and hydrogen, which were referred as $700^{\circ} \mathrm{C}$ and $850^{\circ} \mathrm{C}$ preannealing, respectively. The phase formation of $1 \mathrm{D} \mathrm{ZnO}$ was analyzed by X-ray diffraction (XRD, Rigaku D/MaxRC, Japan). Scanning electron microscopes (SEM, JEOL JSM 6500F, Japan; Cambridge S360, UK) were used to observe the growth morphology. Microstructural characterization of nanowires was conducted by a transmission electron microscope (TEM, FEI Tecnai F20G ${ }^{2}$, The Netherlands). 


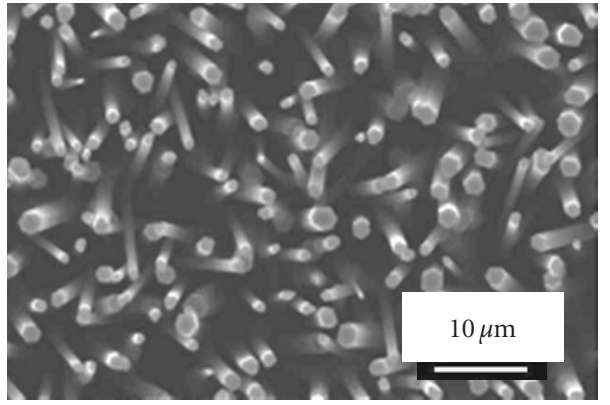

(a)

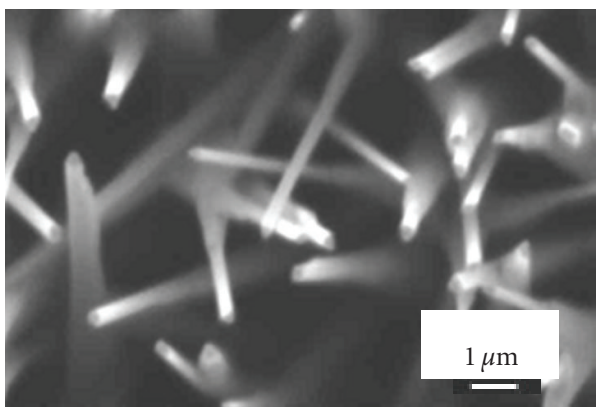

(b)

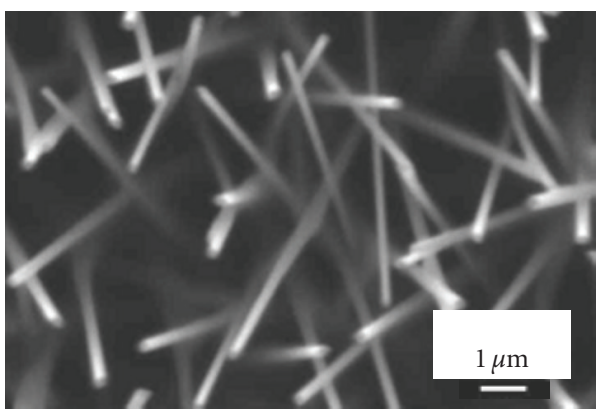

(c)

FIGURE 6: Surface morphologies of $\mathrm{ZnO}$ grown at $700^{\circ} \mathrm{C}$ for $2 \mathrm{~h}$ on (a) untreated, (b) $700^{\circ} \mathrm{C}$ preannealed, and (c) $850^{\circ} \mathrm{C}$ preannealed $\mathrm{Sn} / \mathrm{Ni}$ substrates by thermal evaporation with a $\mathrm{Zn}$ mixture of $\mathrm{Zn}$ and $\mathrm{ZnO}$ in a weight ratio of $1: 1$.

The energy dispersive spectroscopies equipped on SEM and TEM were used to semiquantitatively analyze the phase composition. Room-temperature photoluminescence (PL) measurements were performed using a $325 \mathrm{~nm} \mathrm{He}-\mathrm{Cd}$ laser as the excitation source.

\section{Results and Discussion}

3.1. Growth of $\mathrm{ZnO}$ on Unilayer Catalyst-Covered Substrates. To choose the $\mathrm{Zn}$ source for thermal evaporation, seven sources were tested at $800^{\circ} \mathrm{C}$. The pure zinc produced the $\mathrm{ZnO}$ polycrystalline films with a large grain size of 3-10 $\mu \mathrm{m}$. $\mathrm{Au}$ nanoparticles instead of $1 \mathrm{D} \mathrm{ZnO}$ were observed on substrates when $\mathrm{ZnO}, \mathrm{ZnCl}_{2}$, and $\mathrm{ZnO}+\mathrm{ZnCl}_{2}$ were used. Loose $\mathrm{ZnO}$ grains were obtained with the $\mathrm{Zn}$ sources of $\mathrm{Zn}+\mathrm{ZnCl}_{2}$ and $\mathrm{Zn}+\mathrm{ZnCl}_{2}+\mathrm{ZnO}$. The only successful source for this study of growing $1 \mathrm{D} \mathrm{ZnO}$ was $\mathrm{Zn}+\mathrm{ZnO}$. The next step is to find the appropriate growth temperature. Figure 1 shows surface morphologies of $\mathrm{ZnO}$ grown at (a) $600^{\circ} \mathrm{C}$, (b) $700^{\circ} \mathrm{C}$, (c) $800^{\circ} \mathrm{C}$, and (d) $900^{\circ} \mathrm{C}$ for $2 \mathrm{~h}$ on Au-coated substrates by thermal evaporation with a $\mathrm{Zn}$ mixture of $\mathrm{Zn}$ and $\mathrm{ZnO}$ in a weight ratio of $1: 1$. The growth temperature of $700^{\circ} \mathrm{C}$ was enough to form $\mathrm{ZnO}$ nanowires with a diameter of $100-120 \mathrm{~nm}$ and the length of hundreds of microns. The mixture of submicron-sized $\mathrm{ZnO}$ rods and $\mathrm{ZnO}$ nanorods was observed at growth temperature of $600^{\circ} \mathrm{C}$. Microsized $\mathrm{ZnO}$ polycrystalline layers were obtained at $900^{\circ} \mathrm{C}$. The growth temperature of $700^{\circ} \mathrm{C}$ was chosen for the following experiments.

Figure 2 shows surface morphologies of $\mathrm{ZnO}$ grown at $700^{\circ} \mathrm{C}$ for $2 \mathrm{~h}$ on $\mathrm{Au}$-coated substrates by thermal evaporation with a $\mathrm{Zn}$ mixture of $\mathrm{Zn}$ and $\mathrm{ZnO}$ in weight ratios of (a) $2: 1$, (b) $1: 1$, and (c) $1: 2$. Hexagonal-shaped $\mathrm{ZnO}$ microrods with a diameter of $1.5-3.5 \mu \mathrm{m}$ were obtained at the $\mathrm{Zn} / \mathrm{ZnO}$ ratio of $2: 1$. Similar $\mathrm{ZnO}$ rods with a diameter of $300-600 \mathrm{~nm}$ were grown at the $\mathrm{Zn} / \mathrm{ZnO}$ ratio of $1: 2$. The best condition was at the $\mathrm{Zn} / \mathrm{ZnO}$ ratio of $1: 1$ to obtain $\mathrm{ZnO}$ nanowires with a diameter of $\sim 100 \mathrm{~nm}$. Different sizes of $1 \mathrm{D}$ $\mathrm{ZnO}$ were obtained at the different $\mathrm{Zn} / \mathrm{ZnO}$ ratios. Because these three experiments were conducted on the same type of Au-covered substrates, the sizes of the Au catalysts were expected to be the same. The obtained $1 \mathrm{D} \mathrm{ZnO}$ in different sizes indicates the $\mathrm{Zn} / \mathrm{ZnO}_{x}$ vapor pressure is important in determining their morphologies. That is the reason why reports with the $\mathrm{Zn}$ metal as a source material had different results in nanowires [5] or in nanorods [3, 4]. The other evidence is that the larger sizes of the $1 \mathrm{D} \mathrm{ZnO}$ will form the hexagonal shape, which will be explained at the next section about the bilayer catalysts.

Before bilayer catalysts with $\mathrm{Sn}$ at the top layer were investigated, the effects of unilayer $\mathrm{Al}_{-}, \mathrm{Ni}-$, In-, and $\mathrm{Sn}-$ sputtered catalysts on the growth of $1 \mathrm{D} \mathrm{ZnO}$ were tested. Figure 3 displays surface morphologies of $\mathrm{ZnO}$ grown at $700^{\circ} \mathrm{C}$ for $2 \mathrm{~h}$ on (a) Al-, (b) Ni-, (c) In-, and (d) Sn-coated substrates by thermal evaporation with a $\mathrm{Zn}$ mixture of $\mathrm{Zn}$ and $\mathrm{ZnO}$ in a weight ratio of $1: 1$. Large-grained $\mathrm{ZnO}$ layers were produced at the Al- and In-covered substrates. Nanopencils were obtained on the Ni-coated substrates. $\mathrm{ZnO}$ nanowires with a diameter of $20 \sim 100 \mathrm{~nm}$ were obtained on the Sn-coated substrates. Among catalysts of $\mathrm{Au}, \mathrm{Al}, \mathrm{Ni}, \mathrm{In}$, and $\mathrm{Sn}$, the sputtering coated $\mathrm{Au}$ and $\mathrm{Sn}$ films were the two available catalysts for our system to generate $1 \mathrm{D} \mathrm{ZnO}$. Sn droplets were observed at the tips of the grown $1 \mathrm{D} \mathrm{ZnO}$ when $\mathrm{Sn}$ or $\mathrm{SnO}_{2}$ was used in a mixture with $\mathrm{ZnO}$ powders for an evaporation source $[13,15]$. In this work, Sn was directly deposited on substrates, and the grown $1 \mathrm{D} \mathrm{ZnO}$ had no liquid droplets on its tips.

3.2. Growth of $\mathrm{ZnO}$ on Bilayer Catalyst-Covered Substrates. The bilayer catalysts sputtered on substrates for the growth of $1 \mathrm{D} \mathrm{ZnO}$ included $\mathrm{Sn} / \mathrm{Au}, \mathrm{Sn} / \mathrm{Al}, \mathrm{Sn} / \mathrm{Ni}$, and $\mathrm{Sn} / \mathrm{In}$. Figure 4 shows surface morphologies of $\mathrm{ZnO}$ grown at $700^{\circ} \mathrm{C}$ for $2 \mathrm{~h}$ on (a) untreated, (b) $700^{\circ} \mathrm{C}$ preannealed, and (c) $850^{\circ} \mathrm{C}$ preannealed $\mathrm{Sn} / \mathrm{Au}$ substrates by thermal evaporation with 


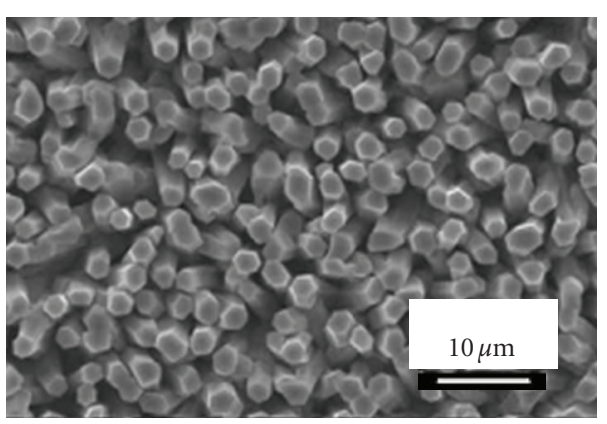

(a)

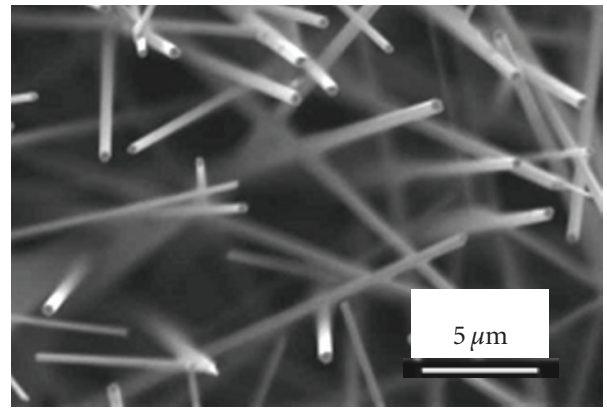

(c)

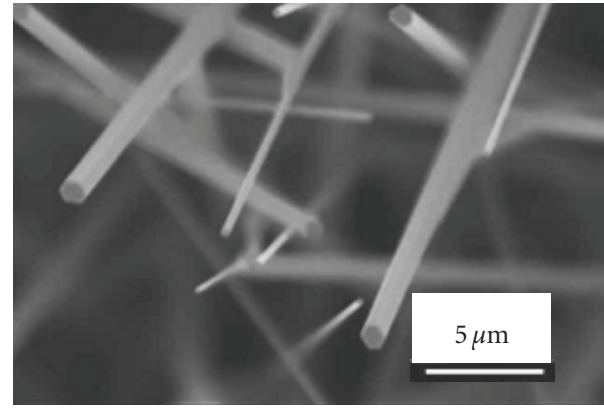

(b)

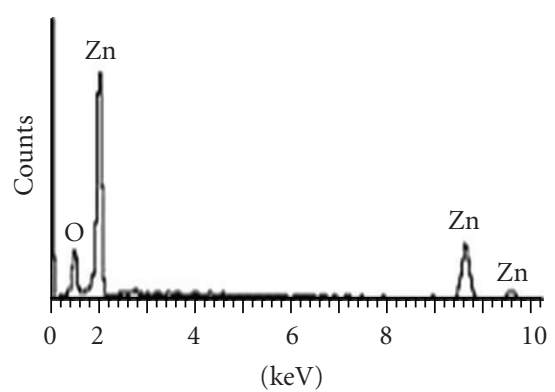

(d)

Figure 7: Surface morphologies of $\mathrm{ZnO}$ grown at $700^{\circ} \mathrm{C}$ for $2 \mathrm{~h}$ on (a) untreated, (b) $700^{\circ} \mathrm{C}$ preannealed, and (c) $850^{\circ} \mathrm{C}$ preannealed $\mathrm{Sn} / \mathrm{In}$ substrates by thermal evaporation with a $\mathrm{Zn}$ mixture of $\mathrm{Zn}$ and $\mathrm{ZnO}$ in a weight ratio of $1: 1$. (d) EDS spectrum of the SEM image in (c).

a $\mathrm{Zn}$ mixture of $\mathrm{Zn}$ and $\mathrm{ZnO}$ in a weight ratio of $1: 1$. $\mathrm{ZnO}$ nanowires with sharp tips of $\sim 50 \mathrm{~nm}$ were obtained on untreated substrates. After preannealing, the grown $\mathrm{ZnO}$ rods had a hexagonal tip. 1D $\mathrm{ZnO}$ had sizes of $0.8-2.0 \mu \mathrm{m}$ and $1.0-2.0 \mu \mathrm{m}$ in diameter after they were grown on the $700^{\circ} \mathrm{C}$ and $850^{\circ} \mathrm{C}$ preannealed substrates, respectively. The diameters of $1 \mathrm{D} \mathrm{ZnO}$ became larger, and the shape changed to microrods after preannealing at higher temperatures. For the $\mathrm{Sn} / \mathrm{Au}$ system as an example (Figure 4), different preannealing treatments have led to different $\mathrm{ZnO}$ sizes. The untreated $\mathrm{Sn} / \mathrm{Au}$ system can produce the $\mathrm{ZnO}$ rods with a uniform diameter, while the system preannealed at $850^{\circ} \mathrm{C}$ obtained hexagonal rods with different sizes. Different preannealing treatments on the bilayer catalystcovered substrates are to change the size, shape, or surface energy of catalysts by alloying, interdiffusion, or reactions of the bilayer components.

Figure 5 shows surface morphologies of $\mathrm{ZnO}$ grown at $700^{\circ} \mathrm{C}$ for $2 \mathrm{~h}$ on (a) untreated, (b) $700^{\circ} \mathrm{C}$ preannealed, and (c) $850^{\circ} \mathrm{C}$ preannealed $\mathrm{Sn} / \mathrm{Al}$ substrates by thermal evaporation with a $\mathrm{Zn}$ mixture of $\mathrm{Zn}$ and $\mathrm{ZnO}$ in a weight ratio of $1: 1$. $\mathrm{ZnO}$ microrods with a diameter of $1.0-2.0 \mu \mathrm{m}$ had a hexagonal shape at its cross-section. The $700^{\circ} \mathrm{C}$ and $850^{\circ} \mathrm{C}$ preannealed substrates grew nanorods of $150-500 \mathrm{~nm}$ and $150-300 \mathrm{~nm}$ in diameter, respectively. Figure 5(d) displays the X-ray diffraction patterns of $\mathrm{ZnO}$ nanorods grown on three types of Sn/Al substrates. All the three typed $1 \mathrm{D} \mathrm{ZnO}$ with a wurtzite structure had the preferred growth direction of [0002].
Figure 6 shows surface morphologies of $\mathrm{ZnO}$ grown at $700^{\circ} \mathrm{C}$ for $2 \mathrm{~h}$ on (a) untreated, (b) $700^{\circ} \mathrm{C}$ preannealed, and (c) $850^{\circ} \mathrm{C}$ preannealed $\mathrm{Sn} / \mathrm{Ni}$ substrates by thermal evaporation with a $\mathrm{Zn}$ mixture of $\mathrm{Zn}$ and $\mathrm{ZnO}$ in a weight ratio of $1: 1$. 1D $\mathrm{ZnO}$ had dimensions of $1.0-2.5 \mu \mathrm{m}, 100-$ $200 \mathrm{~nm}$, and $70-150 \mathrm{~nm}$ for those grown on the untreated, $700^{\circ} \mathrm{C}$ preannealed, and $850^{\circ} \mathrm{C}$ preannealed substrates covered with $\mathrm{Sn} / \mathrm{Ni}$ catalysts, respectively. The dimension of $1 \mathrm{D} \mathrm{ZnO}$ reduced with a preannealing treatment at higher temperatures. The smaller diameters after preannealing at higher temperatures for the $\mathrm{Sn} / \mathrm{Ni}$ system are different for the $\mathrm{Sn} / \mathrm{Au}$ system in Figure 4. The major differences of these two systems are the capabilities of (1) forming spheroids for $\mathrm{Au}$ and $\mathrm{Ni}$ and (2) forming liquid catalyst templates or making templates as spheroids after preannealing. In the bilayer $\mathrm{Sn} / \mathrm{Ni}$ system, the formation of intermediate compounds retards the formation of liquid templates and leads to the Sn$\mathrm{Ni}$ liquid constricted on the Ni-based catalyst layers, which might contribute to the smaller-diameter rods. Basically, the comparative experiments indicate that the surface energy and the shape of bilayer templates will be changed for the different alloy systems. By adjusting the surface energy of templates via the manipulation of solubility of the second element in the $\mathrm{ZnO}$-grown catalysts can modify the size of $\mathrm{ZnO}$ nanorods.

Figure 7 shows surface morphologies of $\mathrm{ZnO}$ grown at $700^{\circ} \mathrm{C}$ for $2 \mathrm{~h}$ on (a) untreated, (b) $700^{\circ} \mathrm{C}$ preannealed, and (c) $850^{\circ} \mathrm{C}$ preannealed $\mathrm{Sn} / \mathrm{In}$ substrates by thermal evaporation with a $\mathrm{Zn}$ mixture of $\mathrm{Zn}$ and $\mathrm{ZnO}$ in a weight 


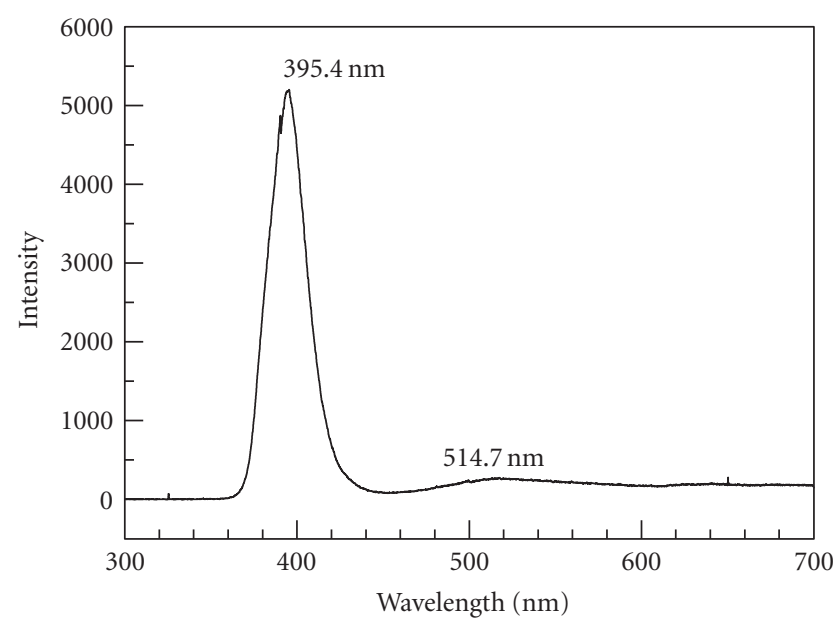

(a)

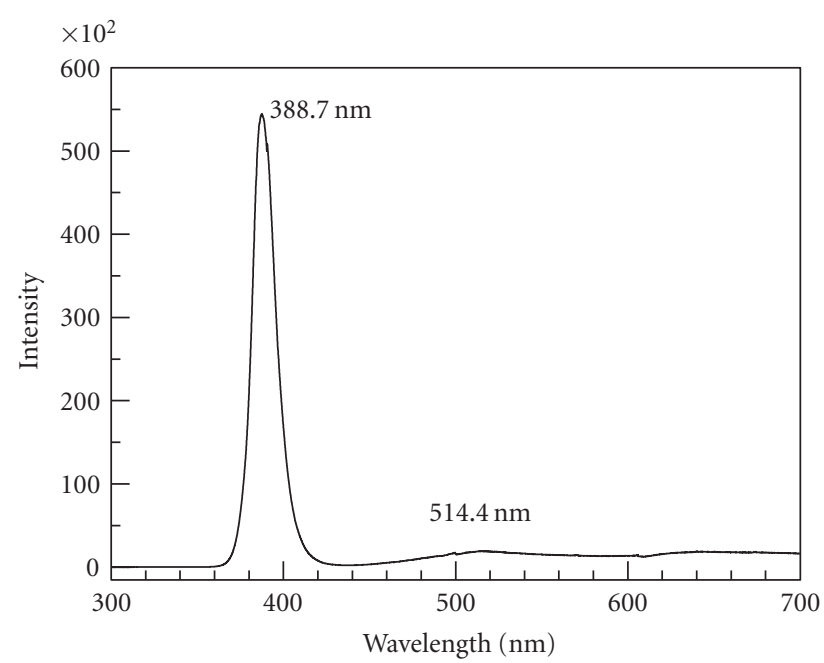

(b)

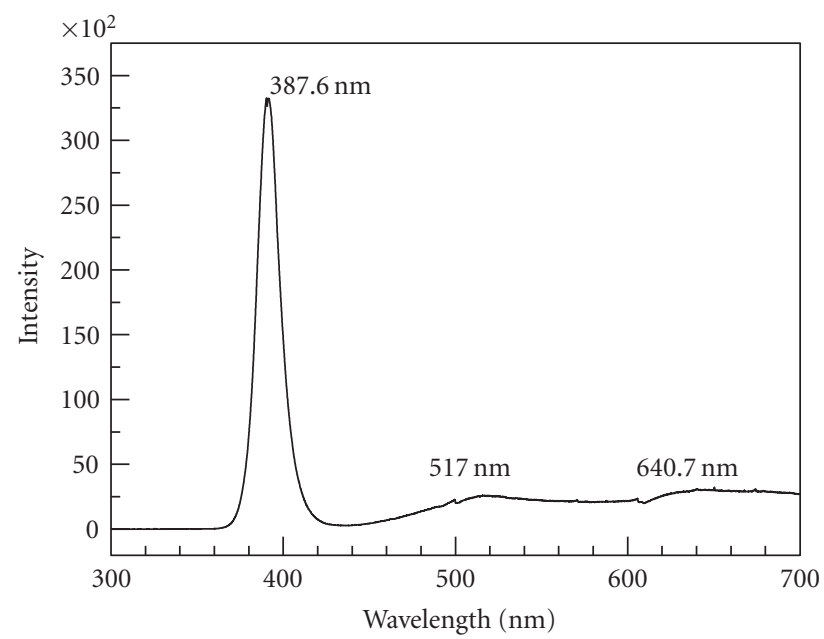

(c)

Figure 8: Photoluminescence spectra of $\mathrm{ZnO}$ grown at $700^{\circ} \mathrm{C}$ for $2 \mathrm{~h}$ on (a) untreated, (b) $700^{\circ} \mathrm{C}$ preannealed, and (c) $850^{\circ} \mathrm{C}$ preannealed $\mathrm{Sn} / \mathrm{Al}$ substrates by thermal evaporation with a $\mathrm{Zn}$ mixture of $\mathrm{Zn}$ and $\mathrm{ZnO}$ in a weight ratio of $1: 1$.

ratio of $1: 1$. $1 \mathrm{D} \mathrm{ZnO}$ had dimensions of $1.5-2.0 \mu \mathrm{m}$, bimodal $0.7 \mu \mathrm{m} / 70 \mathrm{~nm}$, and $80-400 \mathrm{~nm}$ for those grown on the untreated, $700^{\circ} \mathrm{C}$ preannealed, and $850^{\circ} \mathrm{C}$ preannealed substrates covered with $\mathrm{Sn} / \mathrm{In}$ catalysts, respectively. The dimensions of $1 \mathrm{D} \mathrm{ZnO}$ after preannealing had a larger variation. The $700^{\circ} \mathrm{C}$ preannealed substrates led to two types of dimensions of $0.7 \mu \mathrm{m}$ and $70 \mathrm{~nm}$. The dimension of $1 \mathrm{D} \mathrm{ZnO}$ grown on the $850^{\circ} \mathrm{C}$ preannealed substrates ranged between $80 \mathrm{~nm}$ and $400 \mathrm{~nm}$. Therefore, the substrates covered with the bilayer Sn/In catalysts were not suitable for growing $1 \mathrm{D} \mathrm{ZnO}$ rods with a uniform size. Figure $7(\mathrm{~d})$ shows the EDS spectrum of the $1 \mathrm{D} \mathrm{ZnO}$ in Figure 7(c). Only $\mathrm{Zn}$ and $\mathrm{O}$ were detected without other impurities.

Figure 8 displays the room-temperature photoluminescence spectra of $\mathrm{ZnO}$ grown at $700^{\circ} \mathrm{C}$ for $2 \mathrm{~h}$ on (a) untreated, (b) $700^{\circ} \mathrm{C}$ preannealed, and (c) $850^{\circ} \mathrm{C}$ preannealed $\mathrm{Sn} / \mathrm{Al}$ substrates by thermal evaporation with a $\mathrm{Zn}$ mixture of $\mathrm{Zn}$ and $\mathrm{ZnO}$ in a weight ratio of $1: 1$. There are two stronger peaks. One sharp and strong photoemission peak locates at 387-395 nm (3.20-3.14 eV), which corresponds to the near-band-edge peak. Full width at half maxima (FWHM) values of 210, 126, and $123 \mathrm{meV}$ for the excitonic emissions were obtained from $\mathrm{ZnO}$ on the untreated, $700^{\circ} \mathrm{C}$ preannealed, and $850^{\circ} \mathrm{C}$ preannealed $\mathrm{Sn} / \mathrm{Al}$ substrates, respectively. Small FWHM values indicate the good crystallinity for those rods after preannealing. Furthermore, a broad and weak green emission centered at 514-517 nm (2.41-2.40 eV) was observed, which was defect related.

Preannealing on the Sn/Au-covered substrates led to the micrometer-sized $\mathrm{ZnO}$ rods with a hexagonal shape, while the rods obtained from the Sn/Al-, Sn/Ni-, and Sn/Incoated ones had smaller diameters. Furthermore, most of the $\mathrm{ZnO}$ rods grown on the bilayer catalyst-covered substrates 
displayed a hexagonal cross-section without the evidence of catalyst droplets at their ends, which indicates that a vaporsolid growth mechanism is preferred. The changes in the sizes of $\mathrm{ZnO}$ rods with the different preannealing treatments on different catalyst systems indicate the formation of different sizes of catalyst templates due to the considerations of the surface/interfacial energy. These different-sized templates provide the sites for the catalyst-confined growth via the VS growth mechanism. A similar approach to control diameter has been observed in the unilayer Au catalystcoated system by varying the Au layer thickness [19]. About the considerations of surface/interfacial energy, Cai et al. observed that $\langle 111\rangle$ is the most preferable growth direction for $\mathrm{ZnSe}$ nanowires with larger diameters of $17 \mathrm{~nm}$; that is, the growth direction is mainly determined by the size of the catalyst [20]. His considerations have been based upon the principle that the growth of $\mathrm{ZnSe}$ nanowires is driven by the minimum state of the total system energy.

Our $\mathrm{ZnO}$ rods have a vapor-solid growth mechanism, different from those with the Sn droplets on the tips $[13,15]$. In our experiments, the supplied oxygen and the vaporizing zinc vapor are participating in the growth of $1 \mathrm{D} \mathrm{ZnO}$ at the growth temperature of $700^{\circ} \mathrm{C}$. Because there is no solubility between $\mathrm{Zn}$ and $\mathrm{Sn}$ from the binary Zn-Sn phase diagram, the $\mathrm{Zn}$ vapor after adsorbed on the bilayer $\mathrm{Sn} / \mathrm{Au}$ catalysts does not dissolve into $\mathrm{Sn}-\mathrm{Au}$ melt. The adsorbed $\mathrm{Zn}$ adatoms will combine with oxygen to form the $\mathrm{Zn}-\mathrm{O}$ molecules on catalysts. For the reason of considering surface/interfacial energy, the accumulation and stacking of $\mathrm{Zn}-\mathrm{O}$ molecules on the liquid templates will form the hexagonal plates to obtain the $1 \mathrm{D} \mathrm{ZnO}$ with a [0001] growth orientation. This orientation is favored when the liquid templates have larger sizes [20]. To support in lowering the surface/interfacial energies, the liquid Sn-Au templates should adjust to provide a surface for the hexagonal nuclei by forming a $\mathrm{ZnO} / \mathrm{Sn}$ $\mathrm{Au}$ interface to lower the total free energy. The growth of [0001]-oriented $\mathrm{ZnO}$ rods on the $\mathrm{Sn}$ droplets has shown the interfacial orientation relationship of $(020)_{\mathrm{Sn}} \|(0001)_{\mathrm{ZnO}}$ and $[\overline{101}]_{\mathrm{Sn}} / /[2 \overline{11} 0]_{\mathrm{ZnO}}$ between $\mathrm{ZnO}$ rod and Sn particle [14]. The hexagon in cross-section is preferred due to the lattice match between $(020)_{\mathrm{Sn}}$ and $(0001)_{\mathrm{ZnO}}$. Our liquid SnAu catalyst templates might provide a similar role to obtain hexagonal $\mathrm{ZnO}$ rods.

The approach of using the bilayer catalysts to obtain onedimensional $\mathrm{ZnO}$ with the method of thermal evaporation and oxidation has demonstrated the advantages of adjusting the dimension and growth micromechanism of $\mathrm{ZnO}$ rods. Further investigations and understanding for catalysts in the alloy state are needed in order to have a better control in growing the $\mathrm{ZnO}$ nanorods.

\section{Conclusions}

Hexagonal $\mathrm{ZnO}$ rods have been successfully grown at $700^{\circ} \mathrm{C}$ on the untreated or the preannealed bilayer catalystcovered substrates. The bilayer catalysts fabricated by the d.c. sputtering includes the $\mathrm{Sn}$ (top)/Au(bottom), Sn/Al, $\mathrm{Sn} / \mathrm{Ni}$, and $\mathrm{Sn} / \mathrm{In}$ systems. The preannealing treatment refers to the annealing of catalysts at $700^{\circ} \mathrm{C}$ or $800^{\circ} \mathrm{C}$ in the gas mixture of hydrogen and nitrogen before the substrates are put into the other furnace to grow $1 \mathrm{D} \mathrm{ZnO}$. The bilayer catalyst method has helped us to face growth micromechanism in order to distinguish the different sizes of rods at different catalyst systems and different process conditions. The growth behaviors of Sn-based catalyst systems are strongly affected by the second component located as the bottom layer. The size of the $1 \mathrm{D} \mathrm{ZnO}$ from the $\mathrm{Sn} / \mathrm{Au}$ system becomes larger after preannealing, but it becomes smaller for other catalyst systems. The different behaviors are caused by interdiffusion, reactions, surface tension, and the ability of making catalyst spheroids. The smaller-diameter $\mathrm{ZnO}$ nanorods with a hexagonal cross-section at the size of $70-150 \mathrm{~nm}$ were obtained from the $\mathrm{Sn} / \mathrm{Ni}$ catalyst systems preannealed at $850^{\circ} \mathrm{C}$.

\section{Acknowledgment}

The authors acknowledge the financial support by National Science Council under Grant no. 99-2221-E-011-045.

\section{References}

[1] Z. L. Wang, X. Y. Kong, Y. Ding et al., "Semiconducting and piezoelectric oxide nanostructures induced by polar surfaces," Advanced Functional Materials, vol. 14, no. 10, pp. 943-956, 2004.

[2] Z. L. Wang, " $\mathrm{ZnO}$ nanowire and nanobelt platform for nanotechnology," Materials Science \& Engineering R, vol. 64, no. 3-4, pp. 33-71, 2009.

[3] A. Umar, B. Karunagaran, E. K. Suh, and Y. B. Hahn, "Structural and optical properties of single-crystalline $\mathrm{ZnO}$ nanorods grown on silicon by thermal evaporation," Nanotechnology, vol. 17, no. 16, pp. 4072-4077, 2006.

[4] G. Shen, Y. Bando, B. Liu, D. Golberg, and C. J. Lee, "Characterization and field-emission properties of vertically aligned $\mathrm{ZnO}$ nanonails and nanopencils fabricated by a modified thermal-evaporation process," Advanced Functional Materials, vol. 16, no. 3, pp. 410-416, 2006.

[5] J. Park, H. H. Choi, K. Siebein, and R. K. Singh, "Twostep evaporation process for formation of aligned zinc oxide nanowires," Journal of Crystal Growth, vol. 258, no. 3-4, pp. 342-348, 2003.

[6] B. Xiang, P. Wang, X. Zhang et al., "Rational synthesis of ptype zinc oxide nanowire arrays using simple chemical vapor deposition," Nano Letters, vol. 7, no. 2, pp. 323-328, 2007.

[7] X. Wang, C. J. Summers, and Z. L. Wang, "Large-scale hexagonal-patterned growth of aligned $\mathrm{ZnO}$ nanorods for nano-optoelectronics and nanosensor arrays," Nano Letters, vol. 4, no. 3, pp. 423-426, 2004.

[8] Y. X. Chen, M. Lewis, and W. L. Zhou, "Zno nanostructures fabricated through a double-tube vapor-phase transport synthesis," Journal of Crystal Growth, vol. 282, no. 1-2, pp. 85-93, 2005.

[9] W. I. Park, G. C. Yi, M. Kim, and S. J. Pennycook, "ZnO nanoneedles grown vertically on $\mathrm{Si}$ substrates by non-catalytic vapor-phase epitaxy," Advanced Materials, vol. 14, no. 24, pp. 1841-1843, 2002.

[10] M. C. Jeong, B. Y. Oh, W. Lee, and J. M. Myoung, "Comparative study on the growth characteristics of $\mathrm{ZnO}$ nanowires 
and thin films by metalorganic chemical vapor deposition (MOCVD)," Journal of Crystal Growth, vol. 268, no. 1-2, pp. 149-154, 2004.

[11] H. J. Fan, F. Fleischer, W. Lee et al., "Patterned growth of aligned $\mathrm{ZnO}$ nanowire arrays on sapphire and GaN layers," Superlattices and Microstructures, vol. 36, no. 1-3, pp. 95-105, 2004.

[12] G. D. Yuan, W. J. Zhang, J. S. Jie et al., "p-type $\mathrm{ZnO}$ nanowire arrays," Nano Letters, vol. 8, no. 8, pp. 2591-2597, 2008.

[13] P. X. Gao, Y. Ding, and Z. L. Wang, "Crystallographic orientation-aligned $\mathrm{ZnO}$ nanorods grown by a tin catalyst," Nano Letters, vol. 3, no. 3, pp. 1315-1320, 2003.

[14] Y. Ding, P. X. Gao, and Z. L. Wang, "Catalyst-nanostructure interfacial lattice mismatch in determining the shape of VLS grown nanowires and nanobelts: a case of $\mathrm{Sn} / \mathrm{ZnO}$," Journal of the American Chemical Society, vol. 126, no. 7, pp. 2066-2072, 2004.

[15] J. Zhang, Y. Yang, F. Jiang, B. Xu, and J. Li, "Controlled growth of semiconducting oxides hierarchical nanostructures," Journal of Solid State Chemistry, vol. 178, no. 9, pp. 2804-2810, 2005.

[16] J. X. Wang, S. S. Xie, H. J. Yuan et al., "Synthesis, structure, and photoluminescence of $\mathrm{Zn}_{2} \mathrm{SnO}_{4}$ single-crystal nanobelts and nanorings," Solid State Communications, vol. 131, no. 7, pp. 435-440, 2004.

[17] J. X. Wang, S. S. Xie, Y. Gao et al., "Growth and characterization of axially periodic $\mathrm{Zn}_{2} \mathrm{SnO}_{4}$ (ZTO) nanostructures," Journal of Crystal Growth, vol. 267, no. 1-2, pp. 177-183, 2004.

[18] D. H. Kuo and B. J. Chang, "From preannealing of bilayer catalysts to explore the growth micromechanisms of $\mathrm{ZnO}$ nanorods," Crystal Growth \& Design, vol. 10, no. 2, pp. 977$982,2010$.

[19] M. H. Huang, Y. Wu, H. Feick, N. Tran, E. Weber, and P. Yang, "Catalytic growth of zinc oxide nanowires by vapor transport," Advanced Materials, vol. 13, no. 2, pp. 113-116, 2001.

[20] Y. Cai, S. K. Chan, I. K. Sou, Y. F. Chan, D. S. Su, and N. Wang, "The size-dependent growth direction of ZnSe nanowires," Advanced Materials, vol. 18, no. 1, pp. 109-114, 2006. 

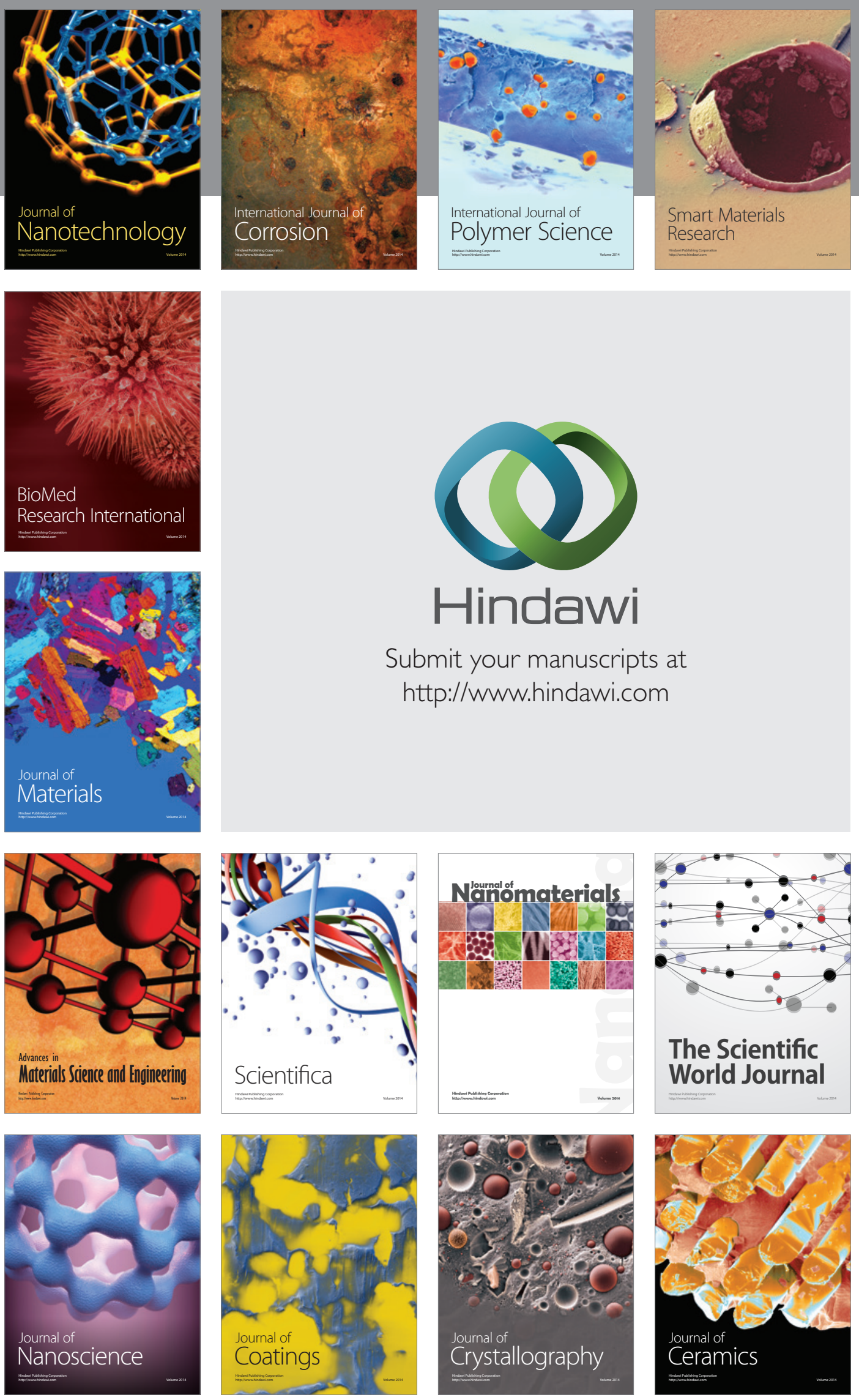

The Scientific World Journal

Submit your manuscripts at

http://www.hindawi.com

\section{World Journal}

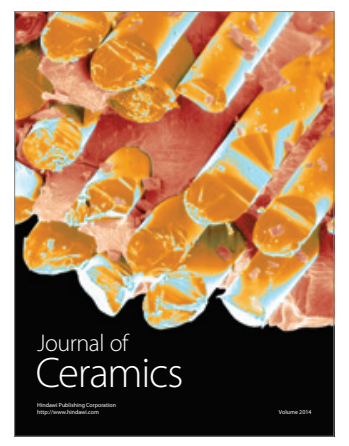

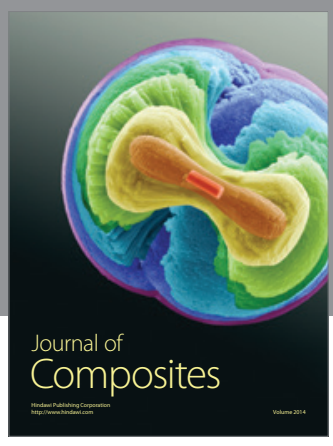
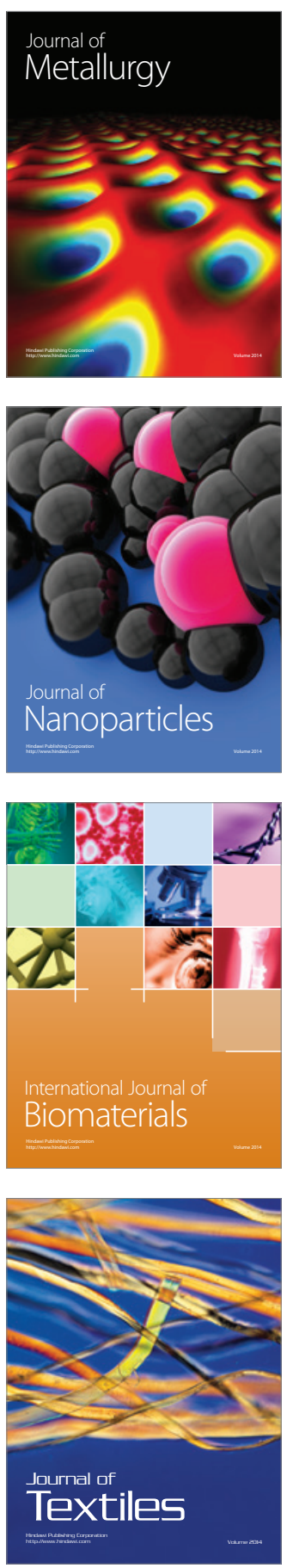